\title{
Trigona sp. Propolis Ethanolic Extract Decreased Chloramphenicol-induced Serum Glutamic Oxaloacetic Transaminase and Alkaline Phosphatase Levels of Rats (Rattus novergicus)
}

\author{
Chanif Mahdi ${ }^{1, *}$, Anna Zukiaturrahmah ${ }^{2}$, Dyah Ayu Oktavianie Ardhiana Pratama ${ }^{2}$, \\ Putranty Widha Nugraheni ${ }^{1}$ \\ ${ }^{1}$ Laboratory of Biochemistry, Department of Chemistry, Faculty of Mathematics and Sciences, Universitas Brawijaya, \\ Malang, Indonesia \\ ${ }^{2}$ Veterinary Study Program, Faculty of Veterinary, Universitas Brawijaya, Malang, Indonesia
}

\begin{abstract}
Liver has an important role in detoxification of toxins such as xenobiotic which could interfere the function of liver. Chloramphenicol is an antibiotic widely used, despite of its toxicity potentials. The enhancement of free radicals in the body could suppress antioxidant activity. Propolis of Trigona sp. has been known to contain very high amount of antioxidants. The enhanced serum glutamic oxaloacetic transaminase (SGOT) and alkaline phosphatase (ALP) levels in serum is used as marker of liver damage due to the increase of free radicals. The purpose of this study was to observe the effect of Trigona sp. propolis ethanolic extract on SGOT and ALP levels in rats (Rattus novergicus) pretreated by chloramphenicol to induce liver damage. Test animals used for this research were male rats aged 8-12 weeks divided into five treatment groups: negative control group (normal), positive control group (induced by $400 \mathrm{mg} / \mathrm{kgBW}$ chloramphenicol), first therapy group, second therapy group, third therapy group induced by chloramphenicol with and propolis extract with the dose of $8 \mathrm{mg}, 16 \mathrm{mg}$, and $24 \mathrm{mg}$, respectively. Chloramphenicol was injected subcutaneously for 14 days, whereas propolis extract were administered orally for 21 days. The level of SGOT and ALP was determined using spectophotometry. The results showed that propolis extract could reduce levels of SGOT and ALP. Dose of $24 \mathrm{mg} / \mathrm{kg}$ was the effective dose to decrease levels of SGOT and ALP significantly $(p<0.01)$. Hence, it may be concluded that the ethanol extract of propolis could be used as herbal therapy in rats model of liver damage.
\end{abstract}

Keywords : ALP, liver, chloramphenicol, propolis, SGOT

\section{INTRODUCTION}

Liver is an organ that have some important functions, such as blood collection, bile production and secretion, metabolism, and detoxification. The liver is the first entrance where the blood of various organs such as the gastric, intestine, pancreas, spleen, and lungs were filtered. As it being large in size, the liver also has more than 500 functions

Submitted: May 22, 2018

Revised: August 21, 2018

Accepted: August 31, 2018

*Corresponding author: chanif@ub.ac.id 
(Hembing, 2008). Toxic substances, whether originated from outside such as drugs or from inside such as metabolic body waste will be detoxified by liver enzymes to be inactive substances. However, there are some chemicals that cannot be conjugated by the liver, which can damage the liver cells. Cells' damage can be caused by alcohol (about 20\%), parasites, viruses and fungi (reached $30 \%$ ), and by drugs (50\%). More than 900 reported drugs could lead to liver damage (Dienstag and Isselbacher 2005).

Drugs that are frequently used are antibiotics. The use of antibiotics that did not meet the rules would cause resistance, allergic reactions, and poisoning. Antibiotics often used for the treatment of typhoid fever in cattle is chloramphenicol, which have some effects on the liver (Hadi, 2007). In cats, chloramphenicol is used in the treatment of otitis, skin disease, respiratory and urinary tract infection (Yanuartono, 2008).

Chloramphenicol is an antibiotic with a broad spectrum, which is naturally produced by Streptomyces venezuelae. Since chloramphenicol is lipophilic, it is rather difficult to be excreted from the body. Chloramphenicol is capable of being xenobiotics for the body. Organ playing the most important role in xenobiotic metabolism is the liver. According to the research of Saba in 2000, it was reported that chloramphenicol had several side effects to the liver. Chloramphenicol could increase the levels of serum glutamic oxaloacetic transaminase (SGOT) or aspartate aminotransferase (AST) enzyme, serum glutamic pyruvic transaminase (SGPT) or alanine aminotransferase (ALT), and alkaline phosphatase (ALP). If chloramphenicol is given in high doses and long periods, it will give toxic effect to the liver due to the chloramphenicol that can damage liver cells.

The substances that are metabolized will be detoxified by a biotransformation process to eliminate harmfull substances. Biotransformation process will go through two phases, that are oxidation and conjugation. However, the biotransformation process does not always produce a safe final product, sometimes some biotransformation processes produce a substance that are more toxic than the initial substance, such as free radicals. This may cause liver damage (Donald, 2004).

There are several possible efforts to protect the liver, by administering drugs, natural products, or chemicals act as hepatoprotectors. Generally, hepatoprotective compounds have high antioxidant activity. One of the natural product that contains high amount of antioxidant is propolis. Propolis is gum collected by bees from various broken plants, then the collected gum is mixed with enzymes in the bee salivary glands. The composition of propolis varies greatly (in color and flavor) and is closely related to the plant type and age, and also the geographical location of propolis origin (Lotfy, 2006). Trigona sp. bees are easily found in tropical and subtropical regions of Southeast Asia. The colony consists of $300,000-800,000$ bees. The honey produced is less much and more difficult to extract, but the amount of propolis produced is higher than the other types (Radiati, et al., 2007).

Research of Bankova, et al. (2000) stated that the result of the propolis extraction by ethanol gave high antioxidant activity. The high flavonoid content in propolis gave strong antioxidant effects to counteract with the radical hydroxyl and radical superoxide which neutralize free radicals resulting in the protection and maintenance of cells' and tissues' integrity, protect the lipid membranes against damaging reactions, thus prevent liver damage (Park, 2002). This research was conducted to study the effect of propolis bee Trigona $s p$. bee propolis ethanolic extract towards AST and ALP levels in rats (Rattus norvegicus) induced by chloramphenicol.

\section{MATERIALS AND METHODS}

\section{Preparation of Test Animals}

Test animals used were 20 Wistar strain white male rats weighing 180-200 g. Rats were being acclimatized for seven days. Rats were fed with 
basal rations containing fiber $(5 \%)$, protein $(20 \%)$, and fats $(5-10 \%)$ in the form of powder or pellets and water ad libitum given regularly. The average daily feed intake of rats was $5 \mathrm{~g} / 100 \mathrm{~g} \mathrm{BW} /$ day (Hamilton, 1998). Furthermore, rats were divided into five treatment groups, that are Negative Control (NC), Positive Control (PC), Treatment 1 (T1), Treatment 2 (T2) and Treatment 3 (T3). Each treatment group consisted of 5 rats. Rats cage sized is $60 \times 40 \times 20 \mathrm{~cm}$ made of stainless steel were designed to accommodate 5 rats. The optimum room temperature for rats is $22-24^{\circ} \mathrm{C}$ and air humidity is $50-60 \%$ with adequate ventilation.

\section{Induction of Chloramphenicol}

Chloramphenicol was given by subcutant injection to induce damage of the liver. Chloramphenicol was injected with a dose of 400 $\mathrm{mg} / \mathrm{kgBW}$ as much as $0.4 \mathrm{~mL}$ once a day for 2 weeks for group PC, T1, T2 and T3 using a $3 \mathrm{~mL}$ syringe. This study was clearly approved by Ethical Committee of Brawijaya University with the certificate number of 344-KEP-UB.

\section{Propolis extraction}

Trigona $s p$. propolis originated from beekeeper in Malang. Propolis extraction using ethanol was conducted according to Harbone and Matienzo (1987). Extraction was done to obtain propolis ethanolic extracts separated from unwanted materials such as wood, sand, and leaves. Extraction was done by maceration using ethanol with one repetition. As much as 100 grams Trigona $s p$. propolis was put in a $1000 \mathrm{~mL}$ ethanol. The mixture was shaken in the dark room and kept for one week. The suspension was filtered using filter paper. Remaceration was done once. Maceration was ended when the last filtrate produced colored clear. Subsequently, after all of the maceration filtrate collected, the filtrate was concentrated by using a rotary evaporator at temperature of $40^{\circ} \mathrm{C}$ and the concentrated extract was weighed in order to obtain the yield. After that, the extract is diluted in propylene glycol one time and the phytochemical test was done (Hardiyanti, 2011).

\section{Flavonoid Test}

As much as $0.3 \mathrm{~mL}$ of propolis with a dilution of 1:2 was mixed with $1.5 \mathrm{~mL}$ methanol and heated to a temperature of $50^{\circ} \mathrm{C}$ for 5 minutes. Five drops of the solution were transferred into test boards and etched with 5 drops of concentrated sulfuric acid. Red color formation indicated that the sample contained flavonoid.

\section{Dose and Treatment of Propolis Ethanolic Extract}

Previous research stated that propolis was safe for consumption. Propolis of Trigona $s p$. extract dose determination refers to the research of Jaya, et al. (2008) administering $0.4 \mathrm{mg} /$ day of propolis as an anti-inflammatory therapy in rats and showed hepatoprotective capability. The $\mathrm{LD}_{50}$ of propolis was more than $10,000 \mathrm{mg}$.

In this study, three variations of dose were used. Treatment of propolis was given by gavaging the fed into gastric. Propolis treatment was given to group T1 (8 mg), T2 (16 mg) and T3 (24 $\mathrm{mg}$ ) orally.

\section{SGOT Examination}

Rats were euthanized by cervical dislocation and dissected in order to take the blood directly from the heart using $5 \mathrm{ml}$ syringes. Blood collected was placed in a venoject tube without EDTA and centrifuged for 10 minutes at $3000 \mathrm{rpm}$. Serum was transferred to a microtube. The determination of SGOT was done by spectrophotometric method (Cintra 5 UV-Visible spectrometer, GBC Scientific Equipment). SGOT examination performed using photometer stardust FC optimization method (Himawan, 2008).

Determination of SGOT activity was based on the enzymatic reaction using Dyasis ${ }^{\circledR}$ 
SGOT kit containing R1: TRIS pH $7.65 \quad 110$ $\mathrm{mmol} / \mathrm{L}$, L-aspartate $320 \mathrm{mmol} / \mathrm{L}$, MDH (malate dehydrogenase) $\geq 800 \mathrm{U} / \mathrm{L}$ and $\mathrm{LDH}$ (lactate dehydrogenase) $\geq 1200 \mathrm{U} / \mathrm{L}$; and R2:2-oksoglutarate $65 \mathrm{mmol} / \mathrm{L}$ and NADH $1 \mathrm{mmol} / \mathrm{L}$.

The sample solution contains a mixture of $\mathrm{R} 1$ and $\mathrm{R} 2$ in a ratio of $4: 1$. A total of $600 \mu \mathrm{L}$ reagent of SGOT kit reacted with $60 \mu \mathrm{L}$ of sample was vortexed and incubated at room temperature for 1 minute. Sample absorbance was determined spectrophotometrically at of $340 \mathrm{~nm}$. SGOT activity determination procedures were based on the working procedures of Dyasis ${ }^{\circledR}$.

\section{ALP Examination}

Determination of ALP activity was done by the enzymatic reaction using ALP Dyasis ${ }^{\circledR}$ kit containing $\mathrm{R} 1$ : diethanolamine $\mathrm{pH} \quad 9.8 \quad 1.2$ $\mathrm{mmol} / \mathrm{L}$ and magnesium chloride $0.6 \mathrm{mmol} / \mathrm{L}$; R2: $\rho$-nitrophenylphosphate $50 \mathrm{mmol} / \mathrm{L}$. The sample solution contains a mixture of $\mathrm{R} 1$ and $\mathrm{R} 2$ with a ratio of 4:1. A total of $600 \mu \mathrm{L}$ reagent kit ALP was mixed with $12 \mu \mathrm{L}$ of sample, vortexed and incubated at room temperature for 1 minute. Sample absorbance was determined spectrophotometrically at $405 \mathrm{~nm}$. ALP activity determination procedures were based on the working procedures of Dyasis ${ }^{\circledR}$.

\section{Data analysis}

This quantitative data were the in the form of a percentage levels of SGOT and ALP tabulated using Excel Microsoft Office then analyzed using analysis of variance (ANOVA) with SPSS 16.0 for Windows software in order to determine any significant differences among the groups. If significant difference was observed, it was then continued by Honestly Significance Difference (HSD) Tukey test with $\alpha=5 \%$ to determine the most effective treatment (Azwar, 2008).

\section{RESULTS}

\section{Effect of Trigona sp. Propolis Ethanolic Extract on SGOT Levels in Rats}

In this research, the effect of Trigona $s p$. propolis ethanolic extract therapy on SGOT level. SGOT is an enzyme whose important function is in protein metabolism, converting them into simpler compounds used as energy source by the cells. SGOT levels in the serum could increase as the result of enzymes release caused by hepatocytes damage.

Research data analyzed statistically using ANOVA and Tukey test showed that SGOT levels of treatment groups were significantly different $(p<0.05)$ (Table 1).

Table 1. Average levels of SGOT in Each Treatment Group.

\begin{tabular}{lccc}
\hline & Average levels of & \multicolumn{2}{c}{ Levels of SGOT } \\
\cline { 3 - 4 } Treatment Group & SGOT (IU/L) & Enhancement (\%) & Reduction (\%) \\
\hline Negative Control (NC) & $131.33 \pm 2.625^{\mathrm{a}}$ & - & - \\
Positive Control (PC) & $198.33 \pm 2.055^{\mathrm{c}}$ & 51.01 & 8.4 \\
$8 \mathrm{mg} /$ rat therapy (T1) & $181.67 \pm 2.867^{\mathrm{b}}$ & 8.73 \\
$16 \mathrm{mg} /$ rat therapy (T2) & $181.00 \pm 2.160^{\mathrm{b}}$ & 31.30 \\
\hline $24 \mathrm{mg} /$ rat therapy (T3) & $136.25 \pm 3.500^{\mathrm{a}}$ & \\
\hline Description: The notations a, b, and c indicate significant difference(s) $(p<0.05)$ between \\
treatment groups. The reduction percentage compared with positive control.
\end{tabular}


Effect of Trigona sp. Propolis Ethanolic Extract Levels on ALP Serum Level in Rats.

This research was conducted to determine the effect of Trigona sp. Propolis ethanolic extracts on liver damage of male Wistar strain rats due to administration of chloramphenicol at a dose of $400 \mathrm{mg} / \mathrm{kg}$. The repair of rat liver damage could be seen as decreased levels of ALP that was measured spectrophotometrically. ALP enzyme is hydrolyzed in the canaliculi membrane of liver cell.

Research data analyzed statistically using ANOVA and HSD test showed significantly different ALP serum levels $(p<0.05)$ between the treatment groups (Table 2 ).

\section{DISCUSSION}

Based on the ANOVA followed by HSD Tukey statistical analysis, significant difference between treatments were observed $(p<0.05)$ (Table 1). SGOT serum level in the $\mathrm{NC}$ group was $131.33 \pm 2.625^{\mathrm{a}}$ IU/L. According to Mitruka (1981), normal level of AST enzyme is equal to $141 \pm 6.74 \mathrm{IU} / \mathrm{L}$. So the result of the $\mathrm{NC}$ group were in the normal range of SGOT enzyme level, since it was given standard feed only without chloramphenicol and propolis treatment, the body was able to balance the amount of free radicals and antioxidants. The balance between endogenous ROS and antioxidants could lower oxidative stress resulting in the inhibition of lipid peroxidation and inflammation, thereby reducing the occurrence of liver cells damage. SGOT is normally synthesized in the liver cells. AST enzymes have a role in the metabolism of the amino acid by converting aspartic acid to alpha chetoglutarate acid which then is broken down into glutamate acid and oxaloacetate. In brief, the liver cells of $\mathrm{NC}$ group rats were in a normal state.

SGOT serum level of PC group was $198.33 \pm 2,055 \mathrm{c}$ IU/L, showed a $51.01 \%$ increase. HSD test showed that levels of SGOT in the PC group were significantly different to the $\mathrm{NC}, \mathrm{T} 1$, $\mathrm{T} 2$ and T3 groups. It was above the normal level of SGOT in serum. Elevated levels of SGOT showed an increase in oxidative stress in the body caused by $400 \mathrm{mg} / \mathrm{kgBW}$ chloramphenicol induction administered subcutaneously for two weeks that cause the liver damage due to the increase of free radicals. It was consistent with the previous studies stating that chloramphenicol was capable to reversibly bind the 50s ribosomal subunits and inhibit protein synthesis at the peptidyltransferase

Table 2 Average levels of SGOT in Each Treatment Group.

\begin{tabular}{rcrc} 
& Average levels of & \multicolumn{2}{c}{ Levels of SGOT } \\
\cline { 3 - 4 } Treatment Group & SGOT (IU/L) & Enhancement (\%) & Reduction (\%) \\
\hline Negative Control (NC) & $103.25 \pm 2.872^{\mathrm{a}}$ & - & - \\
Positive Control (PC) & $209.00 \pm 16.573^{\mathrm{c}}$ & 102.42 & 4.18 \\
$8 \mathrm{mg} /$ rat Therapy (T1) & $200.25 \pm 4.113^{\mathrm{c}}$ & & 21.88 \\
$16 \mathrm{mg} /$ rat Therapy (T2) & $163.25 \pm 8.500^{\mathrm{b}}$ & & 42.94 \\
$24 \mathrm{mg} /$ rat Therapy (T3) & $119.25 \pm 13.889^{\mathrm{a}}$ & & \\
\hline
\end{tabular}

Description: The notations $a, b$, and $c$ indicate significant difference $(s)(p<0.05)$ between treatment groups. The reduction percentage compared with positive control. 
reaction step. In the liver, these drugs suppress the cytochrome P-450 having the role in metabolites oxidation in the liver for further elimination by the kidneys. Increasing workload of a complex enzyme may result in reactive metabolites accumulation in the liver. This then push the ROS in the body to stabilize themselves by binding unsaturated fatty acids contained in the cell membrane, hence affecting liver cell membrane permeability, allowing toxins to enter and damage organelles. Chloramfenicol is widely distributed to all tissues and body fluids, including the central nervous system, so the concentration of chloramphenicol in the brain tissue could be equivalent to the concentration in the serum. Drugs also undergo rapid penetration through cell membrane (Budiono and Herwiyanti, 2000). The damage will cause swelling of the nucleus and the cytoplasm, followed by release of cell contents to extracellular environment due to a disturbance in the sodium pump due to shortage of ATP and if continued could lead to necrosis. This lead to the release of AST into the bloodstream, and so SGOT level increase in rats' serum will be observed.

HSD analysis showed that SGOT levels of $\mathrm{T} 1$ and T2 groups were significantly different compared to $\mathrm{NC}$ group, each giving the value of $181.67 \pm 2,867 \mathrm{~b} \mathrm{IU} / \mathrm{L}$ and $181.00 \pm 2,160 \mathrm{~b} \mathrm{IU} / \mathrm{L}$, respectively. So it could be concluded that propolis administration at the dose of 8 and $16 \mathrm{mg}$ were not able to reduce SGOT levels of chloramphenicolinduced rats. This is due to the low dosage of propolis ethanolic extract given that resulted in lower antioxidant activity that was not adequate to neutralize free radicals in the body.

Statistical analysis showed that SGOT levels of T3 group were comparable to that of NC group. T3 group SGOT level was $136.25 \pm 3,500 \mathrm{a}$ IU/L. A dose of $24 \mathrm{mg} / \mathrm{rat}$ propolis ethanolic extract were efficient for reducing SGOT level optimally as much as $31.30 \%$. This happened because of the role of propolis flavanoid containing Caffeic Phenetyl Acid Ester (CAPE) confirmed by LC/MS that worked as antioxidant. These antioxidants may protect liver cells from the effects of free radicals generated from chloramphenicol metabolism. CAPE was able to donate one hydroxide group to balance the free radicals in the body. So the free radicals in the body could be neutralized, resulting in the decrease in lipid peroxidation, and hence liver damage. Damaged liver cells would then undergo cell regeneration. Therefore, T3 group had similar SGOT level with NC group, supported by the results of histopathological profile (Fitriyatunnisa, 2015). Histolopathological profile of T3 group liver cells showed normal cells traits, which are intact cell membrane, middle-positioned nucleus, and a regular sinusoid, similar to $\mathrm{NC}$ and $\mathrm{T} 1$ group.

ANOVA statistical test showed significant difference $(p<0.05)$ between treatments (Table 2), followed by HSD Tukey test. ALP levels in the NC group was $103.25 \pm 2,872 \mathrm{a}$ IU/L, still within the normal range of $120 \pm 4.76 \mathrm{IU} / \mathrm{L}$, referring to Donatus (1988). This was because the NC group was given standard feed only, without being given chloramphenicol and propolis treatment, so the body were able to balance the amount of free radicals and endogenous antioxidants in the body that inhibited lipid peroxidation which would damage the structure and function of liver cells. Inhibition of liver cell damage can prevent the release of ALP from cells. So the ALP levels were maintained at normal levels.

HSD test showed that ALP level of PC group was significantly different compared to NC group. PC group ALP level was $209.00 \pm 16,573$ c IU/L, which was the highest among all groups, caused by sole chloramphenicol induction without propolis extract treatment. Chloramphenicol with the dose of $400 \mathrm{mg} / \mathrm{kg}$ has exceeded its toxic dose, expected to be able to damage the liver within 2 weeks. This occurs because chloramphenicol could inhibit the action of CP450 in drug metabolism.

Unbalanced free radicals and antioxidants may cause oxidative stress that affect phosphorylation and increase ROS production. These free radicals 
react with polyunsaturated fatty acids which are essential components of cell membranes to produce lipid peroxidation which in turn will change the structure and function of cell membranes.

Increases of cell membrane permeability were followed by a massive influx of calcium and cell death. According to Saba, et al. (2000), Chloramfenicol has been proven to be hepatotoxic, causing the increase of blood liver enzymes levels. Activated inflammatory cells in necrotic hepatocytes cause the release of inflammatory mediators, thereby causing damage to the structure and function of hepatocytes' cell membrane. It was also supported by histopathology profile results of chloramphenicol-induced rats treated with Trigona sp. propolis ethanolic extract (Fitriyatunnisa, 2015). Damage that occurs in the liver lobe caused by ALP release into the blood (Murray, 2009). HSD test results showed that ALP level of T1 group with a dose of $8 \mathrm{mg} / \mathrm{rat}$ was different to $\mathrm{NC}$ but not to PC group. T1 group ALP level was $200.25 \pm 4,113$ c IU/L, close to that of PC group. Thus, propolis ethanolic extract treatment with a dose of $8 \mathrm{mg} / \mathrm{rat}$ was not able to reduce free radicals in the body.

ALP levels of T2 group at a dose of $16 \mathrm{mg} /$ rat was $163.25 \pm 8,500 \mathrm{~b} \mathrm{IU} / \mathrm{L}$, showed a $21.88 \%$ decrease compared to PC group. HSD statistical analysis defined that $\mathrm{T} 2$ group was significantly different to both $\mathrm{NC}$ and PC group, so expected ALP level reduction has not yet been reached.

HSD Tukey statistical analysis showed that ALP levels of T3 group with a dose of $24 \mathrm{mg} / \mathrm{rat}$ propolis extract treatment was similar to NC group, with the value of $119.25 \pm 13,889 \mathrm{a}$ IU/L, showing $42.94 \%$ ALP level reduction. This was because of the role of flavanoid derivatives CAPE that play a role in damaged liver cells repair. Antioxidants are molecules that could slow or prevent the oxidation of other molecules. Oxidation is a chemical reaction in which a transfer of electrons from a substance occurs. These oxidation reactions produce free radicals that start the chain of reactions to destroy cells. Antioxidants terminate these chain of reactions by reducing and inhibiting ROS and inhibit damage to liver cells, by inhibiting lipid peroxidation and keeping the cell structure normal. Increased ALP levels in the serum will then decrease and fall in the normal range (Cotran, 1995).

\section{CONCLUSION}

Trigona sp. propolis ethanolic extract contained flavanoid as active substance could lower AST and ALP enzyme serum level in liver-damaged rats model with the most optimal dose of $24 \mathrm{mg} / \mathrm{rat}$.

\section{ACKNOWLEDGEMENT}

We would like to thank Animal Physiology Laboratory, Islamic University of Malang, Central Laboratory of the Hospital Saiful Anwar Malang, along with all laboratory staffs who helped in this reasearch. The author also wish to thank Ms. Anindyajati, School of Pharmacy, Bandung Institute of Technology for editing the manuscript.

\section{REFERENCES}

Ahmadizadeh, M., Esmail, M., and Goodarzi, Z., 2013, Effect of Phenobarbital on Chloramphenicol Induced Toxicity in Rat Liver and Small Intestine, Iran J. Basic Med. Sci., 16(12), 1282-1285.

Azwar, S., 2008, Penyusunan Skala Psikologi, Yogyakarta: Pustaka Pelajar.

Bankova, V., Truseva B., and Popova, M., 2000, New Developments in Propolis Chemical Diversity Studies. In: Orsolic N, Basic I, ed, 2008, Scientific Evidence of the Use of Propolis in Ethnomedicine, Kerala: Transworld Research Network, pp.1-13.

Budiono, B., and Herwiyanti, S., 2000, Gambaran Histologik Hepar Tikus Putih Setelah Diberi Makan Ekstrak Daun Lamtoro dan Teh Hijau, Jurnal Kedokteran Yarsi, 8(2), 16-24.

Cotran, R.S., 1995, Ginjal dan sistem penyalurannya. In: Robbins, S.L., Kumar, V., and Staf Pengajar Laboratorium Patologi Anatomi Fakultas Kedokteran Universitas Airlangga, ed, 1995, Buku Ajar Patologi II, 4th edition, Jakarta: Penerbit Kedokteran EGC, pp.203. 
Dienstag, L.J. and Isselbacher, K.J., 2005, Toxic and Drug Induced Hepatitis in Harrison Principle of Internal Medicine, 16th edition, Singapore: McGraw Hill, pp.1838-1844.

Donatus, I. A, 1988, Efek Samping Obat: Efek Samping Obat Pada Hepar, Yogyakarta: Yayasan Melati Nusantara.

Donald, C., 2004, Intisari Kimia Farmasi, 2nd edition, Jakarta: Penerbit Kedokteran EGC.

Hadi, S., 2007, Gastroenterologi, 6th edition, Bandung: PT Mandar Maju.

Hamilton, W., 1998, The Mammals of Eastern United States, 3rd edition, New York: Comstock Publishing.

Harborne, J.B., 1987, Metode Fitokimia, Bandung: Penerbit ITB.

Hardiyanti, D., 2011, Pemberian Ekstrak Propolis Peroral Menurunkan Kadar F2-Isoprostan Dalam Urin Tikus Putih (Rattus Novergicus) Jantan Yang Mengalami Aktivitas Fisik Maksimal, Thesis, Universitas Udayana, Denpasar.

Hembing, W., 2008, Tumpas Hepatitis dengan Ramuan Herbal, Jakarta: Pustaka Bunda.

Himawan, R., 2008, Pengaruh Pemberian Ekstrak Daun Teh Hijau (Camellia sinensis) Terhadap Kadar SGPT Tikus Putih (Rattus novergicus) yang Diinduksi Isoniazid, Essay, Universitas Sebelas Maret, Surakarta.
Jaya, F., Radiati, L.E., Al Awwaly, K.U., and Kalsum, U., 2008, Pengaruh Pemberian Ekstrak Propolis Terhadap Sistem Kekebalan Seluler Pada Tikus Putih (Rattus Norvegicus) Strain Wistar, Jurnal Teknologi, 9(1), 1-8.

Lotfy, M., 2006, Biological Activity of Bee Propolis in Health and Disease, Asian Pac. J. Cancer Prev., 7(1), 22-31.

Mitruka, B.M. and Howard, M.R., 1981, Clinical Biochemical Hematological Refrences Value in Normal Experimental Animal and Normal Human, 2nd ed, Chicago: Vear Book Medical Publisher Inc.

Murray, R.K., 2009, Harper's Illustrated Biochemistry, 28th ed, New York: Lange Medical Publications.

Park, Y.K., 2002, Botanical Origin and Chemical Composition of Brazilian Propolis, New York: FAO Agricultural Services.

Radiati, L.E., Thohari, I., and Agustina N.H., 2007, Kajian Propolis, Pollen Dan Royal Jelly Pada Produk Madu Sebagai Antioksidan Alami, Jurnal Ilmu dan Teknologi Hasil Ternak, 2(1), 35-39.

Saba, A.B., Ola, D., Oyeymi, M.O., and Ajala, O., 2000, The Toxic Effect of Prolonged Administration of Chloramphenikol on The Liver and Kidney of Rats, Afr. J. Biomed. Res., 3(3), 133-137.

Yanuartono, 2008, Monitoring Penggunaan Amoksisilin, Ampisilin dan Kloramfenikol pada Kucing di Rumah Sakit Hewan FKH UGM Tahun 2005-2007, Yogyakarta: Universitas Gajah Mada. 